\title{
Do the prophetic and reformist approaches in Christian ethics exclude one another? A responsibility ethics attempt at reconciliation
}

\author{
Author: \\ D. Etienne de Villiers ${ }^{1}$ \\ Affiliation: \\ ${ }^{1}$ Department of Dogmatics \\ and Christian Ethics, \\ University of Pretoria, \\ South Africa \\ Correspondence to: \\ Etienne de Villiers \\ Email: \\ etienne.joan@vodamail.co.za \\ Postal Address: \\ PO Box 294, Pringle Bay \\ 7196, South Africa \\ Dates: \\ Received: 18 Apr. 2011 \\ Accepted: 02 Aug. 2011 \\ Published: 05 Oct. 2012 \\ How to cite this article: \\ De Villiers, D.E., 2012, 'Do \\ the prophetic and reformist \\ approaches in Christian \\ Ethics exclude one another? \\ A responsibility ethics \\ attempt at reconciliation', \\ In die Skriflig/In Luce Verbi \\ 46(1), Art. \#38, 8 pages. \\ http://dx.doi.org/10.4102/ \\ ids.v46i1.38
}

C) 2012. The Authors. Licensee: AOSIS OpenJournals. This work is licensed under the Creative Commons Attribution License.
In the article the view that was expressed in, inter alia, the Kairos Document, that the prophetic and reformist approaches in Christian Ethics exclude one another, was challenged. A case was argued against this view by drawing on Reinhard Kratz's book on the latest research findings on prophecy in the Old Testament, James Gustafson's distinction of four modes of moral discourse and Walter Brueggemann's view that prophetic texts are acts of imagination that offer and purpose 'alternative worlds'. The conclusion was that the prophetic and reformist approaches rather complement, overlap and interpenetrate one another. In the last part of the article an argument was presented that both of the two approaches can be accommodated and integrated in a Christian ethics of responsibility.

Sluit die profetiese en hervormingsbenaderings in die Christelike etiek mekaar uit? 'n Verantwoordelikheidsetiese poging tot versoening. In die artikel is standpunt ingeneem teen die beskouing wat onder andere in die Kairos Dokument uitdrukking vind, dat die profetiese en hervormingsbenaderings in die Christelike Etiek mekaar uitsluit. ' $n$ Saak is beredeneer teen hierdie beskouing met ' $n$ beroep op Reinhard Kratz se boek oor die nuutste bevindings oor Ou Testamentiese profesie, James Gustafson se onderskeiding van vier modi van morele diskoers en Walter Brueggemann se beskouing dat profetiese tekste verbeeldingryk aan ons die moontlikheid van 'n alternatiewe wêreld voorhou. Die gevolgtrekking was dat die profetiese en hervormingsbenaderings mekaar eerder aanvul, oorvleuel en bevrug. In die laaste gedeelte van die artikel was geredeneer dat beide hierdie benaderings geakkommodeer en geïntegreer kan word in 'n Christelike etiek van verantwoordelikheid.

\section{Introduction}

Over the last few decades there has been the tendency in especially ecumenical circles to not only regard the prophetic and reformist approach ${ }^{1}$ as mutually exclusive, but to single out the prophetic approach as the authentic Christian one. In, for example, the Kairos Document, published in 1986, prophetic theology is promoted as the only legitimate theology over against both state theology and church theology. The demand by proponents of church theology that the National Party government should reform its unjust policies is denounced, amongst others, because such reforms come from the top and would not bring about real change (Kairos Theologians 1986). It is clear that the Kairos Document makes no allowance for the possibility that the reformist approach could be prophetic or could even be compatible with or complementary to the prophetic approach.

Now we again face the same impasse, this time not so much with regard to the political system of apartheid, but with regard to economic globalisation. Strong prophetic language is used in the Accra Declaration of the World Alliance of Reformed Churches (WARC) of 2004 and the AGAPE Document of the World Council of Churches of 2006 to denounce what is called 'neo-liberal economic globalisation.' The depiction of neo-liberal globalisation as 'ideology', 'idolatry' and 'Mammon' - to refer just to the Accra Declaration - leaves no doubt that it is regarded as 'irreformable' (WARC 2004). The implication is that any reformist approach to economic globalisation by churches (such as the document of the Evangelical Church of Germany on the global economy of 2001) should be regarded as insufficient (for a critical discussion of the three mentioned documents see Bedford-Strohm 2007:8-27).

The question that I would like to address in this article is: 'Do the prophetic and the reformist approaches in Christian ethics as such exclude one another or do they rather complement,

1.The term reformist is used to avoid confusion with the confessional indication Reformed. Reformist approach here refers to an approach that favours gradual, incremental change in politics, the economy and social life over against drastic, revolutionary change. 
overlap and even interpenetrate one another?' I am trying to argue a case in this article, that these two approaches need not by seen as opposites but can be interpreted in such a way that they indeed complement, overlap and interpenetrate one another. In order to do that I take issue in the first part of the article with the view that the two approaches as such exclude one another. I argue that the foundation of such a view is weak, because it is based on interpretations of both reform and prophecy that do not hold water. In the second part of the article I turn my attention to James Gustafson's influential distinction of four varieties of moral discourse, because I am of the opinion that he helps us on the way to a more satisfactory view of the relationship between the prophetic and reformist approaches. In the last part of the article I am presenting the main thesis, namely that both the prophetic and reformist approach in Christian ethics can be accommodated and integrated in a Christian ethics of responsibility. In the process of doing that, I present my own view of a Christian ethics of responsibility and demonstrate ways in which the prophetic and reformist approaches - on condition that they are understood correctly - can complement and inform one another.

\section{The weak foundation of the exclusivist view}

In my opinion one of the main reasons for the prevalence of the view that the prophetic and the reformist approach in Christian ethics exclude one another, is a one-sided and deficient understanding of what reform and prophecy entail.

In the Kairos Document, for example, reform is depicted as concession from the top by the government that does not bring about any real change. This view of reform, as nothing but the rearrangement of deckchairs on a sinking Titanic, is one often found in prophetic denouncements of existing political and economic arrangements in society. It is of course a view that fits in neatly with a radical revolutionary strategy that aims at the total uprooting of political and economic structures. In the end such a view is, however, a very onesided and even biased view of reform. It is of course true that authoritarian governments, such as the one we had in South Africa in the previous political dispensation, often try to counter growing resistance against their discriminatory and oppressive policies by introducing insufficient reforms in the hope that they will appease the opposition. Such insufficiency is, however, not conceptually or empirically an inevitable part of reform. History abounds with examples of reform that brought about real and incisive change. President F.W. de Klerk's announcement in February 1990, that the African National Congress (ANC) would be unbanned and Nelson Mandela be released from prison, is but one such example. This reform measure by De Klerk has not only brought about real change, but was also intended to do so.

One-sided and deficient understandings of prophecy probably play an even bigger role in the prevalence of the view that the prophetic and reformist approaches exclude one another. I will now mention two of these one-sided and deficient understandings of prophecy.

\section{In terms of the extraordinary personal characteristics of the prophet}

The development and increasing use of the historical-critical method in Old Testament studies at the end of the 19th century brought new insight into the distinctive role and personal characteristics of the group of religious leaders depicted as prophets in the Ancient Near East. Special emphasis was put by Old Testament scholars on the distinctive characteristics of the Old Testament prophets. Interestingly enough, Max Weber, the German sociologist who originally formulated the term ethics of responsibility (Verantwortungsethik), gives extensive attention in his studies on Die Wirtschafsethik der Weltreligionen: Das Antike Judentum, written during the first decade of the 20th century, to Old Testament prophecy. The picture he draws of the prophets provides a fairly accurate reflection of the dominant views of the Old Testament scholars of his time and can serve here as an example. He calls the Old Testament prophets Sendungspropheten, that is, prophets who received a direct calling from Jahwe in one or the other ecstatic experience to go to the people of God and convey his Word to them. They saw themselves as the servants of God, who felt themselves compelled by their calling to convey a specific and sometimes extremely negative and unpopular message of coming disaster and the need for repentance to the disobedient and rebellious people of God. They acted mostly completely on their own, made use of emotional and dramatic language to convey their message in a convincing way and often had to overcome great resistance (Weber 2005:631-648). The picture that Weber draws of the Old Testament prophet is, in other words, that of a heroic, charismatic, lonely and exceptional person (viz. also Otto 2005:202-212).

If this picture of the Old Testament prophet is what one has in mind when one propagates the prophetic approach in Christian ethics, it is of course difficult to see how the reformist approach could be compatible with it. To put it another way: the prophetic approach is then just too high for the reformer to come by. Reformers are typically not persons who can claim to have received a special message directly from God, who stand on their own over against the people of God and make use of dramatic and emotional language. They rather have to work out the implications of God's Word in a particular situation without having absolute certainty that the conclusions they draw accurately reflect his will; have to convince other people by argumentation; work together with them to incrementally make significant changes for the better and for the most part do not make use of dramatic and emotional language.

There is, however, strong consensus among contemporary Old Testament scholars that Old Testament prophecy should not, in the first instance, be understood in terms of the exceptional characteristics of the prophets as persons. As Reinhard Gregor Kratz points out in his book Die Propheten 
Israels (2003:41) it is not so much the biography of the prophets that is conveyed to us in the Old Testament, but rather their books. Central to these books are not the prophets and their actions, but the Word of God, the comprehensive plan of God with his people and the world, that is presented in them and can be known by reading them (Kratz 2003:44). In fact, the conclusion of many decades of Old Testament study is that it is impossible to isolate the original words of the inspired prophets. The Word of God is only given in the interpretation of different authors that were involved in editing and interpreting the books of the prophets. These anonymous co-authors re-interpreted the message of the prophets in order to convey what they perceived as the Word of God to the people of their own time. In the process, different generations rewrote the prophetic books, adding their own actualised interpretation of God's Word. This means that in the prophetic books of the Old Testament we are also - if not for the most part - confronted with the prophetic message of anonymous prophetic scribes whose personal characteristics are of no significance (viz. Kratz 2003:48-49).

\section{In terms of a struggle against a political or economic system}

Both the Kairos Document and the Accra Declaration provide examples of an understanding of prophecy in terms of a struggle against a political or economic system, the Kairos Document perhaps more clearly so than the Accra Declaration. In both, the typical elements of biblical prophecy: the reading of the signs of the time, indictment and the provision of a vision of hope are utilised. In the case of the Kairos Document the move is swiftly made from biblical illustrations of these elements to social analysis in Marxist terms in which the prevalent conflict in South Africa is described as revolution or civil war between an oppressor who is unjust and the oppressor who is just, to complete rejection of the apartheid regime, depicted as tyrannical and 'irreformable' and therefore to be removed to a message of hope that God, who is on the side of the oppressed in their struggle, guarantees liberation from the tyrannical apartheid regime. One of the implications that is drawn out in the final section of the Kairos Document is that the church should also take sides unequivocally and quite simply participate in the struggle for liberation under the leadership of liberation movements (Kairos Theologians 1986).

In the case of the Accra Declaration references to biblical texts that illustrate the different elements of prophecy are also directly linked to a particular economic system. Social analysis is provided in which the real cause of the suffering of the people and damage done to the rest of creation is identified as an unjust economic system imposed by global neo-liberal capitalism and empire, a system of domination led by powerful nations to protect and defend their own interests. This world economic order is depicted as Mammon and strongly rejected because it defies God's covenant with all of creation, based on the vision of justice and peace (WARC 2004). Probably as a result of strong differences of opinion among representatives of the member churches of the WARC, the Accra Declaration does not recommend such strong revolutionary action to churches as in the case of the Kairos Document, although such recommendations would have been consistent with its complete rejection of economic globalisation.

In this interpretation of biblical prophecy and its implications there is indeed no place for the reformist approach. If prophetic attention to the concrete situation is reduced to the exposure of particular oppressive and unjust political and economic systems, prophetic criticism is reduced to the complete rejection of such systems and the prophetic message of hope is reduced to the guarantee that they will be overthrown because God is on the side of those who struggle against them, the reformist approach has to be rejected as hopelessly inadequate.

The problem with this ideological reduction of the prophetic approach is that it does not adequately reflect the biblical message on prophetic witness in its fullness and in some respects even goes against its general drift. It is true that the Old Testament prophets in many instances relate their message to the concrete situation and even to specific political crises in which Israel found itself. The prophetic analysis of the situation, indictment and vision of hope that form part and parcel of the prophetic message, however, never had as aim to legitimise war or rebellion against the political enemies of Israel by demonising the enemy and guaranteeing the eventual victory over the enemy because God was on the side of Israel's political struggle. One can rather say that the Old Testament prophets radically theologised the political crises in which Israel found itself. The cause of dire situations of political oppression and exile was, for the most part, found in the unfaithfulness of the Israelites to God and to his 'Torah' and in God's punishment of such unfaithfulness. The indictment against idolatry, injustice against the poor and other transgressions of God's law were therefore mostly directed against the people of Israel and their political and religious leaders. And the aim of the visions of deliverance was to give the Israelites hope by assuring them that God remained faithful in spite of their unfaithfulness and would eventually liberate them from political oppression and material deprivation on condition that they repent and mend their wrong ways.

What is of special importance in the context of this article is that biblical prophetic witness is never based on the assumption that those against whom the lamentations, indictments or threats are directed are irredeemable or 'irreformable'. To the contrary: as a result of the fact that such lamentations, indictment or threats were mostly directed at the Israelites on the basis of their covenantal relationship with God, their main aim was precisely to appeal to the Israelites and their leaders to repent, to confess their sins and to mend their ways. In many instances this implied the need for reform: in the case of kings, reform of their unjust and oppressive policies and in the case of the rich reform of their exploitative actions against the poor. 


\section{Towards a more satisfactory view of the relationship}

My conclusion in the previous paragraph is that the view that the prophetic and reformist approaches exclude one another is based on one-sided and deficient understandings of reform and prophecy. What would be a more satisfactory view of the relationship between the two approaches?

In my opinion James Gustafson's well-known distinction of four varieties of moral discourse: prophetic, narrative, ethical and policy, can help us on our way. He regards all four of these varieties as legitimate modes of moral discourse. For our present discussion Gustafson's views on especially the prophetic and policy modes of moral discourse are important.

According to Gustafson two aspects distinguish the prophetic mode from the others:

Firstly, it takes the form of moral or religious indictments. Prophetic indictments have two features. Firstly, they usually - though not always - address what the prophet perceives to be the root of religious, moral or social waywardness. They do not analyse possible solutions to quite specific problems, but rather get to the roots of systemic evils that pervade institutions and cultures or the actions and behaviour of individual persons. 'Prophetic discourse generally looks for a demon, a power or source, which presumably underlies all the numerous signs of what is wrong in society' (Gustafson 1988:11). The second feature of prophetic indictments is the language and symbols that are used to make it. They are directed at the 'heart' as well as the 'head'. The prophet usually does not make an argument, but rather demonstrates, shows and tells (Gustafson 1988:11).

Secondly, it portrays an alluring utopia or vision of the future, of possibilities for life in the world in which the forms of strife and suffering we experience are overcome. To quote Gustafson (1988):

The utopian allure is, we are told over and over, not only important, but necessary. It provides hope in the midst of despair, it lifts the eyes and the aspirations beyond what hard realists see as possible to the possibilities that lie beyond. (p. 14)

Gustafson (1988) is of the opinion that prophetic moral discourse locates the problems of humanity at deeper levels than do ethical and policy discourse and stirs our moral sentiments. It is, however, not sufficient, because it involves a necessary simplification of very complex problems and issues. To quote him again:

If prophetic discourse ... is judged to be the sole and proper mode of moral discourse by Christian leaders ... a huge barrier is created between prophetic voices and those that speak in more precise and rational modes of argumentation, and ... those whose callings require of them to make choices within complex institutions and in difficult policy issues. (p. 17)

I also give attention to the fourth mode of moral discourse Gustafson distinguishes, namely policy, because I am of the opinion that it is especially the user of such moral discourse who would be prone to favour the reformist approach. By policy discourse Gustafson means the type of discourse that seeks to recommend or prescribe quite particular courses of action about specific issues. Certain features distinguish policy discourse: quite specific factual matters have to be known and their significance understood, the range of things to be kept in mind is far more complex than a prophet normally keeps in mind, persons responsible for policy have to be sensitive to their own positions of power and choices have to be made among alternatives that are not ideal, but are circumscribed by the reality of institutions and events in which they participate (Gustafson 1988:46).

Gustafson highlights two features of policy discourse. Firstly, it is not conducted by external observers, but by the persons who have the responsibility to make choices and to carry out the actions that are required by the choices. It is, in other words, discourse by the agents who are accountable for the following actions and outcomes. The second feature is the particularity of conditions within which policy is developed. These conditions both limit the possibilities of action and enable them. As a result of this, the first question of the policymaker is likely to be 'what is going on?' and not 'what ought we to do?' The reason is that what is desirable is always related to what is possible; it is always under the constraints of the possible (Gustafson 1988:47). Policy discourse therefore does not and cannot only rely on normative ethical concepts and insights, but also has to make use of sociological, political, economic and other concepts and information (Gustafson 1988:50).

As in the case of the other modes of moral discourse Gustafson (1988) is of the opinion that policy discourse, though important, has its limitations:

Policy discourse necessarily works within limited visions, limited frames of reference. It accepts certain conditions which from prophetic and ethical perspectives could themselves be judged morally wrong or at least morally inadequate. (p. 51)

I am of the opinion that Gustafson helps us forward in more than one way. Firstly he demonstrates in a convincing way that there is not only one legitimate type of moral discourse. It is also not the case that there is a hierarchy of modes of moral discourse and that one particular mode is more authentically moral than the others. This is important, especially in the light of the tendency in some ecumenical circles - for example the circle of Kairos theologians - to regard the prophecy mode as the highest, if not the only authentically Christian mode of moral discourse. Secondly, Gustafson explains to some extent why these different modes of moral discourse have developed over time. It has, at least in the case of prophetical, ethical and policy discourse, to do with one's position in society. The prophet is mostly someone, like the church leader, who is in a position to be an engaged observer and can in solidarity with particular stakeholders criticise the actions and policies of other agents from outside. The ethicist is mostly someone, like the academic theologian and philosopher, who is in a position to be a distanced observer and can try to make as objective as possible, moral observations from the outside. And the policymaker is mostly someone, like the manager or the politician - who is in a position to be 
an involved insider, who can influence economic and political developments in society, and is accountable for his or her actions and the following outcomes. Thirdly, Gustafson also convincingly argues that not one of these modes of moral discourse is all-sufficient, but that they complement and correct one another and are therefore all, indispensable. I want to add also a fourth way by which Gustafson helps us forward. He also helps us to locate the sphere in which the reformist approach in ethics mostly operates. Although it is possible for the narrator, and probable for the academic ethicist, to favour the more incremental approach to change of the reformer, it is most probable, but not inevitable, that the policymaker would favour the reformist approach. The fact that she has to formulate morally sound policies in a complex context in which a myriad of factors have to be taken into account makes it rather unlikely that she would opt for a radical approach to change.

In the context of the present investigation one also has to point out certain shortcomings of Gustafson's distinction. Firstly, his distinction is a purely formal one. One may ask whether a purely formal approach in terms of a mode of discourse regarding prophecy provides us with an adequate account of the prophetic approach in especially Christian ethics. In terms of the features of prophetic discourse that Gustafson points out one, for example, also has to characterise the denouncement of the liberation struggle in strong religious language by government agencies in the previous political dispensation in South Africa as being prophetic. The liberation movement was depicted by them as communist and communism was identified by them as the root cause of everything that went wrong in South Africa. From a Christian perspective the depiction of such an approach as prophetic seems hardly adequate. The only way to avoid such inadequate depictions would in my opinion be to identify certain substantive criteria for an adequate prophetic approach in Christian ethics. A second shortcoming is that Gustafson seems to imply that each one of at least the prophetic, ethical and policy modes of moral discourse is inevitably linked to a particular group of people with a very specific position and role in society. One may ask whether this does not provide too static an account of the linkage of modes of moral discourse to particular users. To put it this way: is it really impossible for the prophet to be a policymaker and for the ethicist and the policymaker to be prophetic? If one has to admit that this is possible, one also has to admit that a prophet needs not necessarily be a revolutionary, but may in particular circumstances favour reform and a policymaker may on occasion opt for more radical change.

Earlier on in this article the conclusion has already been drawn that not so much the charismatic personality of the biblical prophet, or a confrontational, revolutionary and activist stance over against oppressive political and economic powers should be seen as the core of the prophetic approach, but rather the prophetic texts with their peculiar message. In the above discussion of Gustafson's view on the prophetic mode of moral discourse, it has again become clear that a purely formal interpretation of the prophetic approach does not suffice. Substantive criteria are needed in the application of the prophetic approach.

As Reinhard Kratz (2003) in his book on the prophets of Israel emphasises, one does not really bear witness to the message of the prophets by applying it to our own time in a direct and literal way. The books of the prophets are the products of a process of renewed re-interpretation and re-actualisation of the plan of God as unfolded in previously written versions of the prophetic message. The prophetic books invite the readers to do the same thing in their own time: to read and interpret the signs of the time in their interaction with the message on God's plan conveyed in the books (Kratz 2003:45).

Walter Brueggemann puts the same emphasis on the text of the prophetic books in his book The prophetic imagination (1st edn. 1978; 2nd edn. 2001). In the preface to the revised edition of the book he also takes issue with the onesided emphasis on the personality of the prophet and the confrontational nature of prophetic witness. He stresses that prophetic texts 'are acts of imagination that offer and purpose 'alternative worlds' (Brueggemann 2001:x). On the basis of this understanding of the prophetic texts he explores in his book the hypothesis: 'The task of prophetic ministry is to nurture, nourish, and evoke a consciousness and perception alternative to the consciousness and perception of the dominant culture around us' (Brueggemann 2001:3). His interpretation of the central message of the prophetic books is that this alternative consciousness points towards an alternative religion of the freedom of God and an alternative politics of justice and compassion. It serves on the one hand to criticise the dismantling of the dominant consciousness. On the other hand, it serves to energise persons and communities by its promise of another time and situation toward which the community of faith may move (Brueggemann 2001:3-9).

If we take our point of departure from this understanding of biblical prophecy, there is no need to conclude that the prophetic and the reformist approaches in Christian ethics exclude one another. If the aim of the prophetic approach is to nurture the alternative consciousness that enables us to criticise the dominant culture and to energise us to work for an alternative world - which is characterised by justice and compassion - and it is the aim of the reformist approach to constructively and incrementally work for the optimal realisation of this ideal world, then these two approaches can be seen as complementing, overlapping and even interpenetrating one another.

\section{The integration of the two approaches in Christian ethics of responsibility}

In this last part of the article I would like to demonstrate how the prophetic and reformist approaches could be accommodated and integrated into a Christian ethics of responsibility. Such an endeavour may at first glance seem to be a rather improbable pursuit. For is it not the case that 
the term responsibility is frequently used by policymakers who favour a reformist approach and is just too 'tame' to be in any way associated with the prophetic approach with its fiery overtones?

It cannot be denied that the ethics of responsibility has in the past often been associated with the reformist approach. That has, amongst others, to do with the fact that Max Weber, one of the founders of the discipline of Sociology, has firstly used the term ethics of responsibility to indicate an ethical approach that stands in opposition to an ethical approach that would by many in Christian circles be regarded as prophetic. In his famous speech Politik als Beruf (The profession and vocation of politics) presented in 1919, Max Weber took to task those Christians who regarded their own interpretation of the moral message of the Bible as the sole and final measure of political policies and actions. In this article he specifically criticised Christian pacifist politicians who campaigned for the abolishment of the German army on the basis of their understanding of the Sermon on the Mount. He depicted them as proponents of an ethics of conviction (Gesinnungsethik). According to Weber it is typical of proponents of such an ethics to apply their religiouslyinspired moral convictions in an abstract and absolutist way without taking into account: the specific nature of politics, the particular role of responsibility that they as politicians have, and the disastrous consequences the decision to abolish the German army and ban the use of military force, could have. They are only interested in obeying what they believe the will of God is, and they are quite happy to leave the responsibility for the consequences of their decisions to the almighty God who in his providence determines the outcome of events in accordance with his will (Weber 1994).

In opposition to the ethics of conviction Weber proposed an ethics of responsibility (Verantwortungsethik). In contrast to politicians who adhere to an ethics of conviction, politicians who adhere to an ethics of responsibility would be willing to:

- take full personal responsibility for deciding on the right political actions

- take the specific nature of politics as a separate life sphere with its own principles and demands seriously (including what Weber calls die Sache of politics: the maintenance of order)

- take their particular role responsibility as politicians - to do what is needed to maintain order - and not only what they regard as their moral responsibility, seriously and

- seriously consider the consequences their political decisions could have on the political power play, before taking and implementing such decisions (Weber 1994:309-369).

In my opinion Weber has convincingly demonstrated that social ethics - and that includes Christian social ethics - is not a simple matter of mechanically applying only moral principles in particular circumstances. It is a much more complicated matter in which a particular person or group of persons has to take responsibility for thoroughly analysing the concrete situation and deliberating the possible consequences of different options for action, but also for weighing up different value systems that are in play, before making a decision on the right action. It is especially important to not only consider moral values based on the Bible and to ignore the functional values that are valid in the different social systems (e.g. in economy: efficiency and productivity), as well as the cultural values of a particular people (for example the $u b u n t u$ values of African people).

What I would like to suggest is that the adequate, contemporary Christian social ethics that we today need in the South African society, cannot but be an ethics of responsibility (cf. De Villiers 2003:23-38, 2005:521-536). It is only when Christian social ethics is conceived as ethics of responsibility that justice can be done to both the Christian moral tradition and the achievements of modernisation, including the differentiation of modern societies into relatively independent social systems. Only then would it also be possible to take adequate account in Christian social ethics of the different cultures of the peoples of South Africa.

Does that now mean that I choose in favour of the reformist approach and against the prophetic approach in Christian ethics? My answer is 'no!' on condition that the prophetic approach is not restricted to a confrontational and activist style as is the case in the Kairos Document.

I am of the opinion that even Max Weber believed that the responsible politician should have something of the prophet in him. The politicians of conviction clearly saw themselves as prophets, but they were in Weber's opinion misguided and irresponsible prophets who were not willing to face the restrictions and prerequisites of processes of modernisation like rationalisation and bureaucratisation and to deal with them in a realistic way. They instead preferred to ignore harsh realities and flee into an idealistic, make-belief world, sometimes with disastrous political consequences. The responsible and charismatic politician on the other hand, is one who is willing to face the restrictions of real politics, and courageously takes the actions needed to optimally realise at least some of the values he treasures. In contrast to the politicians of conviction he is heroically willing to answer the call of history by doing what is necessary to make a difference in this world in spite of the restraints.

That is not to say that the Christian ethicist who wants to accommodate the prophetic approach in an ethics of responsibility can suffice with Weber's view on such an ethics. Weber was no Christian. There are certainly aspects of his view on the ethics of responsibility that are problematic from a Christian perspective. Weber, for example, uses the image of polytheism to describe the different value systems of which the ethics of responsibility has to take account (Weber 1968:507,603). This image, however, suggests that the system of moral values has no priority over the other value systems, but has to compete on an equal footing with these other value systems for recognition. Which values in the end prevail depends fully on the preferences and final decision of the charismatic politician. From a Christian perspective the central moral values that we believe are an expression of the 
moral will of God do have some priority. It is true that this priority is not an absolute one, in the sense that moral values always completely replace functional values that seem to be in tension with it. Functional and cultural values are, for the most part, not in opposition to moral values, but, as valid in their own right, complement them. The challenge that we are faced with in a Christian ethics of responsibility is to facilitate between the moral, functional and cultural value systems in such a way that they are all accommodated optimally.

This is not to deny that functional and cultural values can sometimes be in strong opposition to moral values that are central to Christians. This is, for example, the case when functional values, which are valid in a particular social sphere, start to play an imperialistic role in other social systems. A valid economic value, such as competition, can cause havoc if it becomes dominant in the family setting. For this reason William Schweiker is of the opinion that the role of moral and religious values over against other values is primarily a limiting one, namely, to prevent them from claiming validity outside their sphere of competence (Schweiker 2000:128139). Schweiker seems to imply that the difference between moral and other values lies in the fact that moral values have trans-systemic validity, whilst other values only have intrasystemic validity. If he is right the trans-systemic nature of moral values may be one way of conceiving their priority with regard to other values. Their priority comes into play not only when functional and cultural values overstep the limits of their sphere of competency, but also when perverted versions of them become prevalent within social systems. For example, even in business the 'dog eats dog' interpretation of competition is never acceptable from a Christian moral perspective. In other words, the priority of moral values consists - at least partly - in the indispensable limiting role they play with regard to other values, both on the borders of and within social systems.

This exposition of the critical role that moral values can and should play with regard to social systems is, in my opinion, already a clear indication that a Christian ethics of responsibility can accommodate the prophetic approach with its emphasis on fundamental criticism. In order to fully accommodate the prophetic approach - as interpreted by me - room should also be made within a Christian ethics of responsibility for the guiding and energising role moral considerations play in the prophetic approach. This guiding and energising role is provided in the prophetic approach for the most part by an inspiring vision of an ideal, new world in which justice, peace and compassion prevail. There is no reason why such a vision of an ideal world cannot be part and parcel of a Christian ethics of responsibility. It can form one pole and the emphasis on realism the other pole of an indispensable creative tension in such an ethics, which could ensure the optimal realisation of the moral ideals that form part of the vision.

To conclude the following three scenarios will illustrate how the prophetic impulse could function in three different types of situations.

\section{Extreme totalitarianism}

In a situation of extreme totalitarianism in which all calls for reform would have no effect, like for example in Nazi Germany, the responsible approach for Christians would indeed be to take a confrontational and activist stance, not to collaborate with the totalitarian state and participate in efforts to overthrow it. It was in such a situation that Dietrich Bonhoeffer decided to participate in the effort to assassinate Adolf Hitler, although he believed as a Christian that it was wrong to take the life of a fellow human being. Interestingly enough, he called the decision in such a dilemmatic situation to do what was necessary - although it was morally wrong the exercise of 'free responsibility' (Bonhoeffer 2005:273-274).

\section{Serious discrimination and oppression}

In an in-between situation where there is serious discrimination and oppression, but there is still for some Christians the prospect of influencing government policies and contributing to real systemic changes, one has to accept that different groups of Christians would have different views of what a responsible approach entails. I believe that this was the situation in South Africa during the previous political dispensation, at least during the 1980s. Black Christians were in no position to persuade the government to abolish its discriminatory policies and accept majority rule through normal political channels. They rightly decided, after all other avenues had proven to lead nowhere, to take a confrontational and activist stance and to take measures to overthrow the government. Other, mostly White Christians, who were convinced that they still had some influence on fellow Christian politicians and voters regarded the most responsible thing to do, to directly appeal to them. I am not now talking of those White people, who excused themselves from criticising the government by saying that they would help to change the system from inside, and in the end did nothing significantly. I am talking of people like Dawid Bosch, Willie Jonker, Willem Nicol, Klaus Nürnberger, Koos Vorster and numerous others, who not only strongly criticised the government, but also pointed out reform measures that could effectively move us out of the political impasse towards a just future society. By doing that, they were, in my opinion, just as much prophets as the church leaders and theologians who supported the Kairos Document. I also believe that they and other Christian leaders who - like the prophets of the Old Testament - directly appealed to fellow believers to repent their wayward actions and policies, just as much helped to prepare the way for F.W. de Klerk's momentous reform measures of February 1990 as those who put the government under economic and military pressure.

It is a pity that there is no acknowledgement in the Kairos Document of a legitimate reformist approach with a strong prophetic thrust, and no recognition that such an approach could complement the confrontational, revolutionary approach advocated in the document. I just hope that the supporters of the Accra Declaration would not make the same mistake and would realise that they have strong allies among a great number of Christian proponents of a more reformist 
approach. In fact, the proponents of both the prophetic and the reformist approaches should realise that they need one another. Proponents of the reformist approach need the proponents of the prophetic approach to keep them aware of the intensity of the suffering of the poor and the sublimity of the ideal they should try to realise. The proponents of the prophetic approach need the proponents of the reformist approach to identify effective ways of changing the unjust system of economic globalisation and help them to not get stuck in an ineffective confrontational posture.

\section{Intra- and inter-institutional relations}

The first two situations that we have dealt with have to do with the macro political and economic levels. On the micro level of intra-institutional relations and the meso level of inter-institutional relations, the responsible approach would normally be the reformist approach. That does not mean that the prophetic thrust should in such normal situations be totally absent. Even in these situations the prophetic vision should still inspire Christians to formulate what one could call concrete or viable visions of morally desirable states in an institution or in the relationships between institutions. In a religiously and culturally pluralist society such as ours, such an endeavour would of course entail its own challenges.

\section{Conclusion}

My conclusion is therefore that there is no reason to see the prophetic and the reformist approaches in Christian ethics as opposites. Both of them are legitimate Christian approaches. They can be integrated into a Christian ethics of responsibility in a satisfactory way and can be used to complement and inform one another. Such a view is, in my opinion, more convincing than the view of those who elevate either of the two approaches to the position of the most authentic Christian approach. And it definitely provides a more fruitful foundation for the much-needed Christian cooperation in the struggle against injustice in this world.

\section{Acknowledgements}

This article is dedicated to prof. Koos Vorster who, in both the previous political dispensation and the present one, has proven that he is a prophet in the sense advocated in this article.

\section{Competing interests}

The author declares that he has no financial or personal relationship(s) which may have inappropriately influenced him in writing this article.

\section{References}

Bedford-Strohm, H., 2007, 'Public theology and the global economy: Ecumenical thinking between fundamental criticism and reform', Nederduitse Gereformeerde Teologiese Tydskrif 48(1/2), 8-24.

Bonhoeffer, D., 2005, Ethics, Dietrich Bonhoeffer Works, vol. 6, Fortress Press, Minneapolis.

Brueggeman, W., 2001, The prophetic imagination, 2nd edn., Fortress Press, Minneapolis.

De Villiers, D.E., 2003, 'A Christian ethics of responsibility: Does it provide an adequate theoretical framework for dealing with issues of public morality?', Scriptura 82, 23-38.

De Villiers, D.E., 2005, 'The vocation of the Reformed ethicist in the present South African society', Scriptura 89, 521-535.

Gustafson, J., 1988, Varieties of moral discourse: Prophetic, narrative, ethical and policy, Calvin College and Seminary Library, Grand Rapids.

Kairos Theologians, 1986, The Kairos document: Challenge to the church: A theological comment on the political crisis in South Africa, Skotaville, Braamfontein.

Kratz, R.G., 2003, Die Propheten Israels, Beck, Munich.

Otto, E., 2005, 'Die hebräische Prophetie bei Max Weber, Ernst Troeltsch und Hermann Cohen: Ein Diskurs im Weltkrieg zur christlich-jüdischen Kultursynthese', in W. Schluchter \& F.W. Graf (eds.), Asketischer Protestantismus und der 'Geist' des modernen Kapitalismus: Max Weber und Ernst Troeltsch, pp. 201-255, Mohr Siebeck, Tübingen.

Schweiker, W., 2000, 'Responsibility in the world of Mammon: Theology, justice and transnational corporations', in M.L. Stackhouse \& P.J. Paris (eds.), God and globalization, vol. 1, Religion and the powers of the common life, pp. 105-139, Trinity Press International, Harrisburg, Pennsylvania.

Weber, M., 1968, Gesammelte Aufsätze zur Wissenschaftslehre, 3rd edn., JCB Mohr (Paul Siebeck), Tübingen.

Weber, M., 1994, 'The profession and vocation of politics', in P. Lassmann \& R. Speirs (eds.), Weber, Political writings, pp. 309-369, University Press, Cambridge.

Weber, M., 2005, Die Wirtschaftsethik der Weltreligionen: Das Antike Judentum, Mohr Siebeck, Tübingen.

World Alliance of Reformed Churches (WARC), 2004, Covenanting for justice in the economy and the earth, WARC, Accra. 